\title{
Study of the Effects of Two Crop Systems and Best Management Practices on Soil and Water Conservation in Tunisian Semi-arid Area
}

\author{
L. Laajili-Ghezal \\ School of Higher Education in Agriculture, Carthage University, Tunisia
}

Copyright@2018 by authors, all rights reserved. Authors agree that this article remains permanently open access under the terms of the Creative Commons Attribution License 4.0 International License

\begin{abstract}
In Tunisia, water erosion is one of the most important processes affecting around $25 \%$ of arable land, generating a potential loss of soil productivity due to a decrease of hydraulically and chemical stocks. To control water erosion on lands of average slopes (less than 10\%) best management practices (crop rotation, organic fertilization, etc.) have to be developed especially in Tunisian semiarid area, where rainfall irregularity and aggressivity enhance water erosion. Thus, conservative techniques for soil and water protection are required and have to be implemented at the level of the agricultural parcel to maintain or improve the productive potential of soils on average slopes in rain-fed lands, located in Tunisian semi arid area. In this context the article is presented. It is a synthesis of some experimental works on plots of 1 to $4 \mathrm{~m}^{2}$ in the experimental field station of the ESA Mograne, for the study of the effects of different kinds of crop-rotation (fallow long duration- chick pea) and organic fertilizers (row olive mills waste water) on the fertility of the soil and its potential yield. Results showed that long fallow-chickpea rotation and use of $50 \mathrm{~m}^{3} /$ ha of row olive mills waste water improve soil fertility (water retention and $\mathrm{C} / \mathrm{N}$ ). This improvement in water and soil chemical properties increases the components of performance of chickpea (rate of dry matter) and weight of 1000 grains and plant biodiversity for $50 \mathrm{~m}^{3} /$ ha spreading of row olive mills waste water. These results can be valued for the development of strips crops on average slope lands in Tunisian semiarid area for soil and water conservation.
\end{abstract}

Keywords Soil and Water Conservation, Crop Rotation, Moderate Slopes, Best Management Practices, Tunisian Semi-arid Region

\section{Introduction}

Tunisia is characterized by 1 ) a range of varied climates: the humid Mediterranean climate in the North to the desert climate in the South, 2) irregular and aggressive rainfall enhancing soil detachment, especially for poor vegetation cover. Aggressive rainstorms can generate heavy runoff and create important floods and sediment yield affecting hydraulic infrastructures. To solve these problems related to soil water erosion, the Tunisian Government has implemented two strategies for water and soil conservation since 1990. A third national strategy is being prepared by the Directorate of development and Conservation of agricultural land (DG / ACTA), based on an assessment of past achievements and the dynamics of physical and human environments in Tunisia as well as technological developments in the field of natural and human resources.

Thus, during the first 2 strategies, several managements to control water erosion and improve agricultural yield production have been made over large areas. Several small dams were built on hill slope lands during these two strategies allowing groundwater recharge and surface water retention in order to increase and diversify agricultural production and fight against drought and desertification. To control soil water erosion on hilly slopes, the DG/ACTA, through their regional offices, encouraged farmers to crop irrigation, to reduce soil water erosion by perennial plant species and to improve human conditions of the rural population living mainly in disadvantaged areas. For the future decade, Tunisia making part of the Mediterranean basin, which is one of the most vulnerable regions to the announced impact of climate change, agriculture is one of the most affected economic sectors. At the local level, capacity of resilience of communities and populations appear as determinant of medium-term adaptive solutions to ensure food security for the Tunisian population. Cropping systems and conventional agriculture on water productive watersheds as the Medjerda watershed, have affected the physical (suspended solid matter, turbidity) and chemical (nitrates, salts, organic matter ... etc.) water qualities. So to respond to natural and man-made changes 
that know Tunisia, the use of new modes of natural resources management for the conservation of soil and water and local development are needed. This paper is a summary of some research works done at the ESA Mograne within experimental plots, to study the:

1. Effect of chickpea on soil and water conservation after a long fallow period;

2. Effect of the application of three doses of row olive oil waste water on soil and water conservation.

\section{Materiel and Methods}

\subsection{Study of the Effect of Chickpea (Cicer Arietinum L.) on the Fertility of the Soil in Tunisian Semiarid \\ Area}

Agronomic experiment was conducted in Tunisian semiarid area, region of Mograne Zaghouan governorate, using a spring chickpea crop (Amdoun 1 variety), after a long-term fallow soil. The soil texture is Clay loam. The aim of this experiment was to study the effect of the crop on soil fertility (holding water capacity, carbon, organic matter and nitrogen of the soil) and to identify among the variables of fertility those affecting Chickpea production and the components of yield production. Seasonal distribution of rain during the crop year 2001-2002, at the ESA Mograne, showed that $31.2 \%$ of rainfall occurs in the fall, $17.6 \%$ in winter, $34.8 \%$ in spring and $16.4 \%$ in summer, which can justify the choice of the spring chickpea as soil and water conservation crop.

\subsection{Effects of Application of Row Olive Mill Waste Water on Soil Fertility and Weeds}

Olive crop plays a fundamental role in the socio-economic life of the country in view of the tradition of planting of olive in all Tunisia, the nutritional value of olive, the value of exports, jobs and income generated by this sector. In addition, the olive growing contributor to regional balance limiting rural exodus since it is often the only viable crop in less favored areas. In areas where water erosion is active, it is the main cultivated fruit tree (Figure $1)$.

Raw olive mill waste water, an effluent of mills, accumulate from one year to another, and can leads to a real environmental problem related to its polluting power.
Current research in several Mediterranean centers showed the interest of spreading on soil of row olive mill waste water as one of the management solution of these effluents. This solution is used for perennial crops like olive tree as an organic fertilization for environmental conservation and improvement of agricultural product quality. The row olive mill waste water, which is the residual outcome of the process of olives mixing, is viscous reddish brown color, acid smell effluent, very salty and rich in fertilizer element. This liquid waste is mainly generated during the preparation of olives for grinding by washing water, rinsing of the storage hoppers waters and the olive water contain itself.

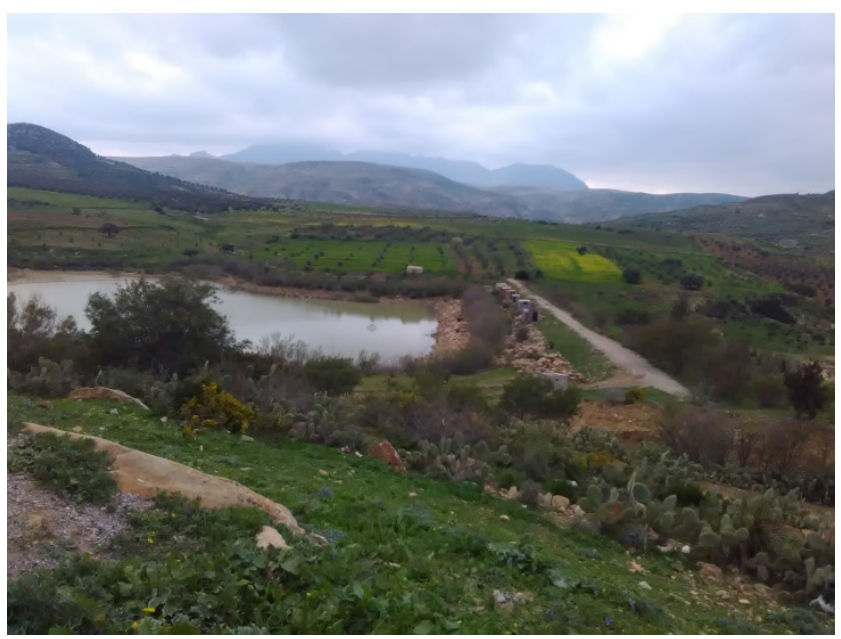

Figure 1. Development of olive trees around the hilly small dam at Zriba Karya in Zaghouan

\section{Raw Olive Mill Waste Water Composition}

As reported by [1], raw olive mill waste water composition differs based on different factors. Indeed, the composition and concentration of this residual water rate depend on the variety of olives, their degree of maturation and the extraction system. In fact the amounts of water added during the crushing process vary from one system to another. According to the authors, olive mill waste water presents an organic fraction and a mineral fraction which differs according to the extraction system.

Table 1 gives the average composition of raw olive mill waste water according to different authors, deducted from the data collected from the bibliography, and a comparison made between the compositions of oil mills effluent generated by different extraction systems. 
Table 1. Average composition of raw olive mill waste water according to different authors [in 1]

\begin{tabular}{|c|c|c|c|c|c|c|}
\hline & Unité & Pompei (1974) & Fiestas (1981) & Steegmans (1992) & Hamadi (1993) & Andreozzi (1998) \\
\hline $\mathrm{pH}$ & & - & 4.7 & 5.3 & $3-5.9$ & 5.1 \\
\hline $\mathrm{CDO}$ & $\mathrm{g} / \mathrm{l}$ & 195 & - & 108.6 & $40-220$ & 121.8 \\
\hline $\mathrm{BDO}_{5}$ & $\mathrm{~g} / \mathrm{l}$ & - & - & 41.3 & $23-100$ & - \\
\hline Suspended Solids & $\mathrm{g} / \mathrm{l}$ & 38.44 & $1-3$ & 19.2 & $1-20$ & 102.5 \\
\hline Total organic solids & $\mathrm{g} / \mathrm{l}$ & - & - & 16.7 & - & 81.6 \\
\hline Fatty matter & $\mathrm{g} / \mathrm{l}$ & - & - & 2.33 & $1-23$ & 9.8 \\
\hline Polyphenols & $\mathrm{g} / \mathrm{l}$ & 17.5 & $3-8$ & 0.002 & $5-80$ & 6.2 \\
\hline Organic acids & $\mathrm{g} / \mathrm{l}$ & - & $5-10$ & 0.78 & $0.8-10$ & 0.96 \\
\hline Total nitrates & $\mathrm{g} / \mathrm{l}$ & 0.81 & $0.3-0.6$ & 0.6 & $0.3-1.2$ & 0.95 \\
\hline
\end{tabular}

As reported by [1], the extraction process affects the composition of olive mill waste waters (table 2).

Table 2. Comparative data of the raw olive waste waters composition based on the olive oil extraction system. [in 1]

\begin{tabular}{|c|c|c|c|}
\hline & Unit & Un continous System & Continous System \\
\hline $\mathrm{pH}$ & & $4.5-5$ & $4.7-5.2$ \\
\hline $\mathrm{CDO}$ & $\mathrm{g} / \mathrm{l}$ & $120-130$ & $35-41$ \\
\hline BDO $_{5}$ & $\mathrm{~g} / \mathrm{l}$ & $90-100$ & 9 \\
\hline Suspended Solids & $\mathrm{g} / \mathrm{l}$ & 1 & 60 \\
\hline Total solids & $\mathrm{g} / \mathrm{l}$ & 120 & 5 \\
\hline Mineral Salts & $\mathrm{g} / \mathrm{l}$ & 15 & 55 \\
\hline Volatils substances & $\mathrm{g} / \mathrm{l}$ & 105 & $3-10$ \\
\hline Lipidic Matter & $\mathrm{g} / \mathrm{l}$ & $0.5-1$ & \\
\hline
\end{tabular}

The basic compounds of raw olive waste water are water (83.2\%), organic chemicals (15\%) and minerals (1.8\%).

The composition of the mineral substance of olive mill waste water gives fertilizer properties (Berndt et al., 1996; Fiestas Ros Di Ursinos and Borja-Padilla, 1996; Parades and al., 1999, in [1]). While the composition of the organic fraction of olive mill waste water in sugar alcohols, pectin, mucilages, tannins and polyphenols (Berndt et al., 1996; Fiestas Ros Di Ursinos and Borja-Padilla, 1996; Parades and al, 1999; in [1]), gives high concentrations of toxic components.

Table 3 gives the physicochemical characteristics of two olive mill waste waters from Sousse and Zaghouan.

Table 3. General characteristics of used olive mill waste water

\begin{tabular}{|c|c|c|c|c|c|}
\hline & $\mathbf{p H}$ & $\mathbf{E C}(\mathrm{mS} / \mathrm{cm})$ & $\mathbf{S E M}(\mathrm{g} / \mathrm{l})$ & Turbidity $(\mathrm{FAU})$ & $\mathbf{C D O}_{\left(\mathrm{mgO}_{2} / \mathrm{l}\right)}$ \\
\hline $\mathbf{M}_{\mathbf{a} 1}$ (Sousse) & 5.26 & 14.60 & 40 & 3670 & 6120 \\
\hline $\mathbf{M}_{\mathbf{a} 2}$ (Zaghouan) & 5.14 & 14.13 & 39,5 & 9630 & 5472 \\
\hline
\end{tabular}

The spreading of a given concentration of olive mill waste water will change the soil surface (Figure 2). 


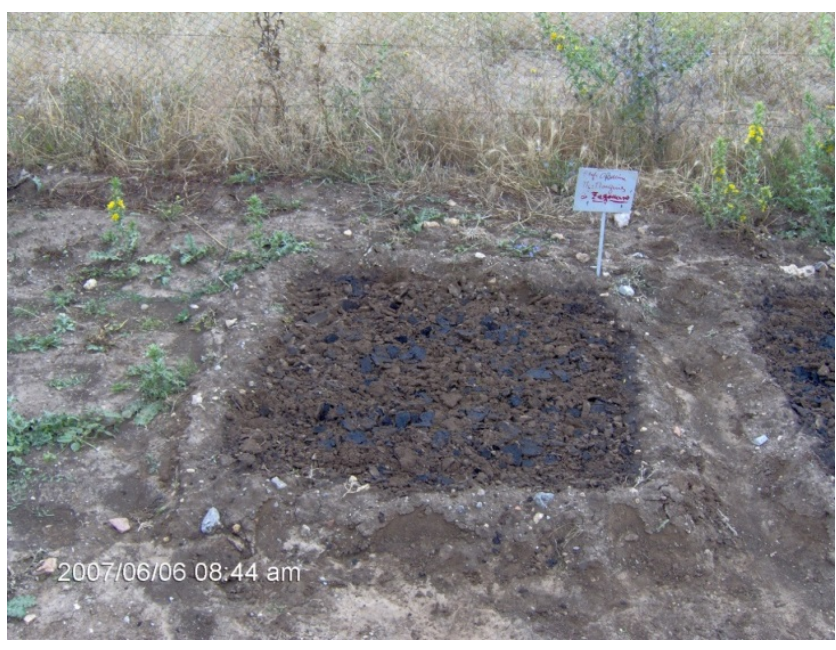

Figure 2. State of the clay-sandy soil after spreading $80 \mathrm{~m} 3$ per hectare of olive mill waste water of Zghouane, June 2007

\section{Results and Discussion}

The first experimental erosion plots were installed in Sidi Thabet and Jouggar (Manouba and Zaghouan Governorates respectively). Indeed, [3] in 1971 has studied soil loss of different types of crop rotation compared to fallow continuously worked in straight furrows parallel to the slope, to farm plots of $5 \%$ of slope. All studied rotation are of type four-year or five-year with a year or 2 years of grain, integrating the Fallows grazed or not grazed, legumes (beans), industrial crops (sugar beet), forage (vetch-oats), improved route (grassland) (Sulla-Phalaris).

\subsection{Effect of Chickpea (Cicer Arietinum L.)}

Results analysis showed that ecologically, use of spring chickpea induced an increase of soil organic matter content between the initial state and the final state of the soil, which varies according to sites (Figure 3).

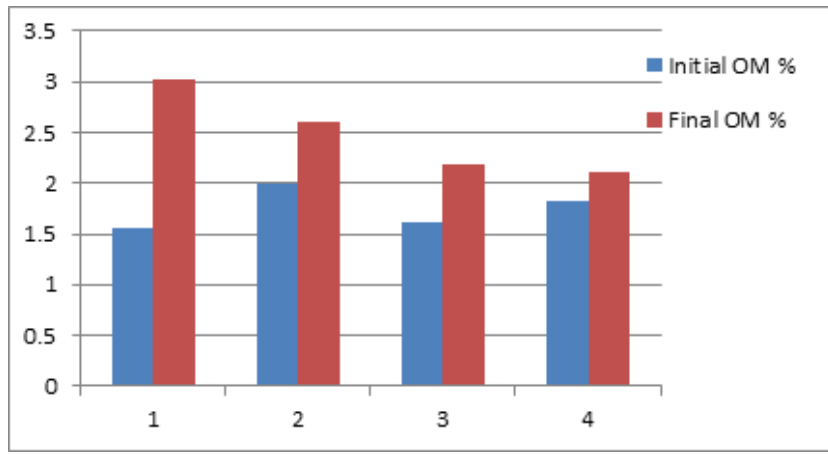

Figure 3. Effect of spring chickpea crop on soil organic matter content for the $0-30 \mathrm{~cm}$ layer for 4 plots within slope direction

The length of the plant and the internodes are strongly correlated with the $\mathrm{C} / \mathrm{N}$ soil ratio after harvesting, while the percentage of dry matter and the weight of 1000 grains are highly correlated with the final soil moisture. Indeed, a simple linear model involving the final soil moisture explains only $98 \%$ and $97 \%$ of the rate of dry matter and the weight of 1000 grains of chickpea respectively. Lengths of the plant and that of the internodes are positively correlated to $\mathrm{C} / \mathrm{N}$ soil ratio which is $98 \%$ and $97 \%$ of the obtained results.

\subsection{Effects of Application of Row Olive Mill Waste Water}

An important concentration of olive mill waste water fertilizer (80-100 $\mathrm{m}^{3} / \mathrm{ha}$ ) resulted in a significant reduction in the bulk density compared to the untreated soil (Figure 4) on the clay-sandy soil, which is related to an increase of the soil total porosity, inducing an improvement of the soil structure. These results corroborate those found by Mellouli (1996), in [1], which showed that the application of olive mill waste water, leads to an increase of total porosity and leeching porosity. This new distribution of soil porosity will induce soil water capacity reduction. There is also an improvement of aeration of the soil as a result of the increase in the leeching porosity.

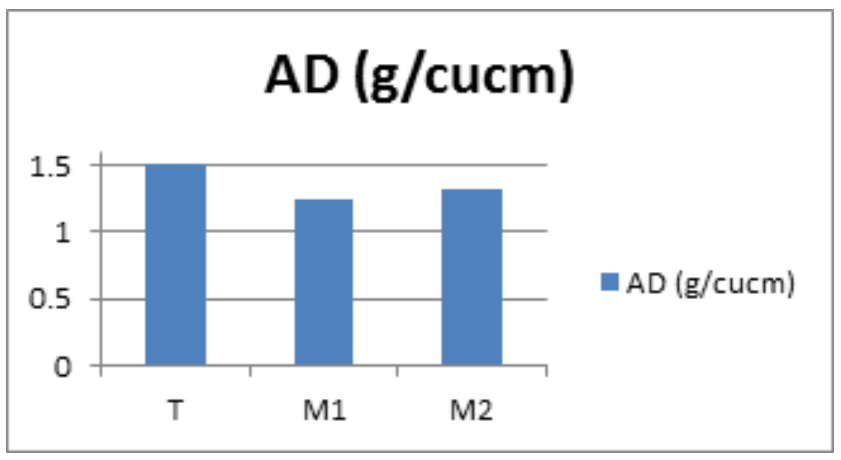

Figure 4. Effects of olive mill waste waters on the bulk density (AD) of the clay-sandy soil taken one month after application of $80 \mathrm{~m}^{3} / \mathrm{ha}$ of olive mill waste waters of Sousse (M1) and (M2) of Zaghouan

Olive mill waste water spreading of $80 \mathrm{~m}^{3} /$ ha generates an increase in the normal shear stress of the soil and therefore a better mechanical resistance of the soil to water erosion.

As a result of this work performed from December 2007 to March 2008. Experimentation carried out was to spread olive mill waste water on experimental plots of $4 \mathrm{~m}^{2}$ area each one. The amounts of applied olive mill waste waters are made in a single application according to three different doses: $\mathrm{T} 1=50 \mathrm{~m}^{3} / \mathrm{ha}$, T2 $=100 \mathrm{~m}^{3} / \mathrm{ha}$ and T3 $=200 \mathrm{~m}^{3} / \mathrm{ha}$. It is a random experimental study: $\mathrm{T0}$ (witness $=$ no spreading of olive mill waste water), T1, T2 and T3. The used olive mill waste water came from directly the decanter of the continuous system for three phases of a modern oil mill located in Zaghouan. This effluent has an acid pH 4.7 and electrical conductivity of $13.08 \mathrm{mS} / \mathrm{cm}$. The soil texture (USDA classification is clay-sandy.

During this experimental study, a follow-up of the soil water holding capacity, as an indicator of soil fertility [2] was used. Figure 5 gives the variation of the soil water holding capacity (mm) for the $20 \mathrm{~cm}$ soil top layer for the 
witness (T0) and T1, T2 and T3 treatments.

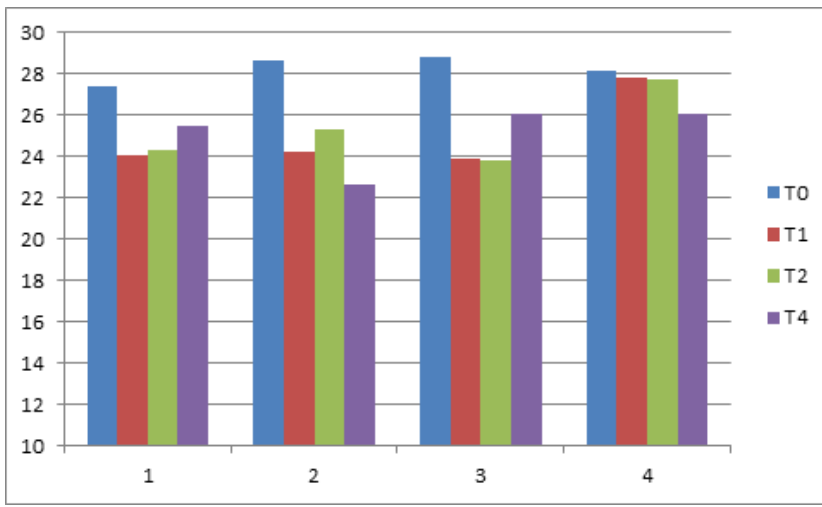

Figure 5. Variation of the soil water holding capacity $(\mathrm{mm})$ for the $20 \mathrm{~cm}$ soil top layer for four months

Results corroborate those found in 2007. So, olive mill waste water increases the soil macro porosity. However, water holding capacities of treated plots become close to the water holding capacity of the witness plot after 4 months of application.

Spreading of olive mill waste water has an effect on the floristic composition (Weeds) of the soil, depending on the treatment (Figure 6).

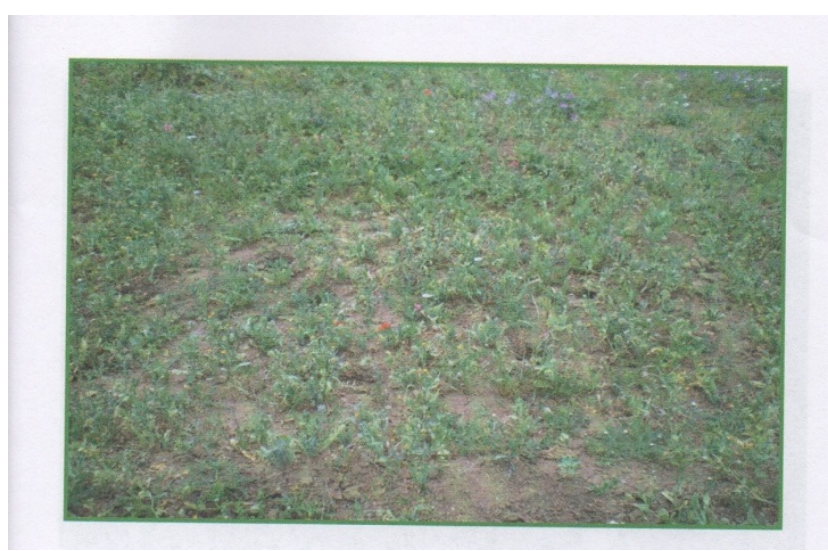

(a)

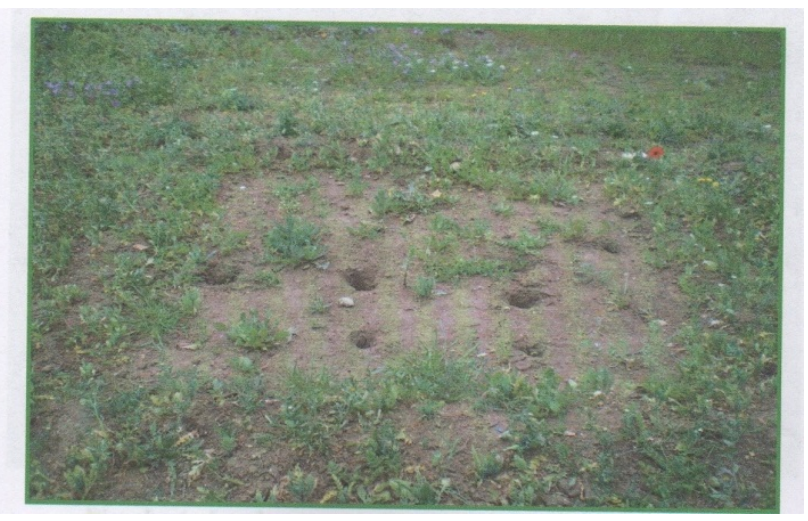

(b)

Figure 6. Effect of the application rate of olive mill waste water has an effect on the floristic composition (Weeds) of the soil for witness plot (a) and T1 plot (b) [1].
Indeed, the floristic richness of the soil depends on the dose of olive mill waste water spread. Table 4 gives the ranking of the species identified in experimental plots by treatment.

Table 4. Classification of weed species identified in experimental plots by treatment [1]

\begin{tabular}{|c|c|}
\hline Weed species (Latin name) & Treatment \\
\hline Hordeum murinum & $\mathrm{T} 0$ \\
\hline Bromus rigidus & $\mathrm{T} 0$ \\
\hline Lolium perenne & $\mathrm{T} 1$ \\
\hline Elytrigia repens & $\mathrm{T} 1, \mathrm{~T} 2$ \\
\hline Catapodium rigidum & $\mathrm{T} 1, \mathrm{~T} 2$ \\
\hline Phalaris paradoxa & $\mathrm{T} 1, \mathrm{~T} 2, \mathrm{~T} 3$ \\
\hline Phalaris brachystachys & $\mathrm{T} 1, \mathrm{~T} 2$ \\
\hline Matricaria chamomilla & $\mathrm{T} 0$ \\
\hline Carduus & $\mathrm{T} 1, \mathrm{~T} 2, \mathrm{~T} 3$ \\
\hline Beta vulgaris & $\mathrm{T} 0$ \\
\hline Chenopodium album & $\mathrm{T} 1, \mathrm{~T} 2$ \\
\hline Plantago major & $\mathrm{T} 1, \mathrm{~T} 2$ \\
\hline Papaver rhoeas & $\mathrm{T} 1, \mathrm{~T} 2$ \\
\hline Polygonum aviculare & $\mathrm{T} 1, \mathrm{~T} 2, \mathrm{~T} 3$ \\
\hline Emex spinosa & $\mathrm{T} 1, \mathrm{~T} 2, \mathrm{~T} 3$ \\
\hline Melilotus indica & $\mathrm{T} 1, \mathrm{~T} 2$ \\
\hline Malva sylvestris & $\mathrm{T} 1, \mathrm{~T} 2, \mathrm{~T} 3$ \\
\hline Anagallis arvensis & $\mathrm{T} 1$ \\
\hline Turgenia latifolia & $\mathrm{T} 1, \mathrm{~T} 2, \mathrm{~T} 3$ \\
\hline
\end{tabular}

\subsection{New Crop Systems for Soil and Water Conservation and Food Security}

Agronomic trials for the study of the effects of cultural associations leading to improvement of soil fertility in rained crops were conducted in semi-arid and arid regions in Africa. As an example we can mention the study of the effect of the association Cowpea-sorghum on runoff and erosion in Burkina Faso (Figure 7).

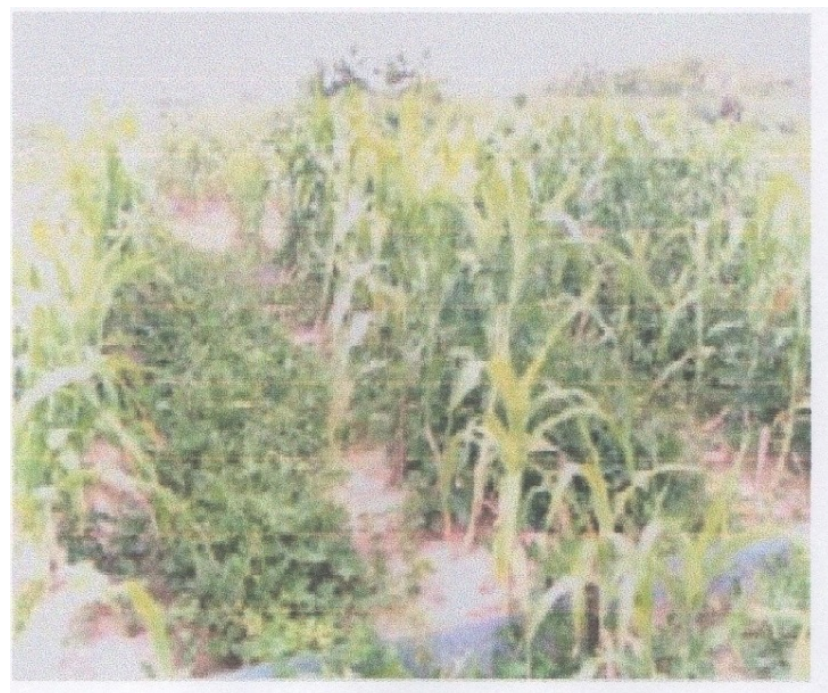

Figure 7. Crop association Cowpea-sorghum in Burkina Faso [4]

According the authors, the results of three years of 
testing have shown that:

- Cowpea-sorghum association allows a reduction in runoff by 20 to $30 \%$ compared to the pure culture of sorghum and $5-10 \%$ compared to that of cowpeas;

- The sorghum-Cowpea association led to an erosion reduction of $80 \%$ compared to the pure culture of sorghum and $45-55 \%$ compared to that of cowpeas.

- $\quad$ Cowpea roots bring nitrogen to soil by symbiotic nitrogen fixation of air; Cowpea-sorghum association is beneficial in terms of agricultural production.

At the ESA Mograne studies have been completed or underway on associations like: Poaceae/legumes and trees/Poaceae/legumes, include the association of cereal/safflower, moringa oleifera (tree rich in protein and vitamins and with multiple uses), stevia (plant used as a sweetener) and others. Figure 8 shows a monoculture moringa oleifera bio plantation.

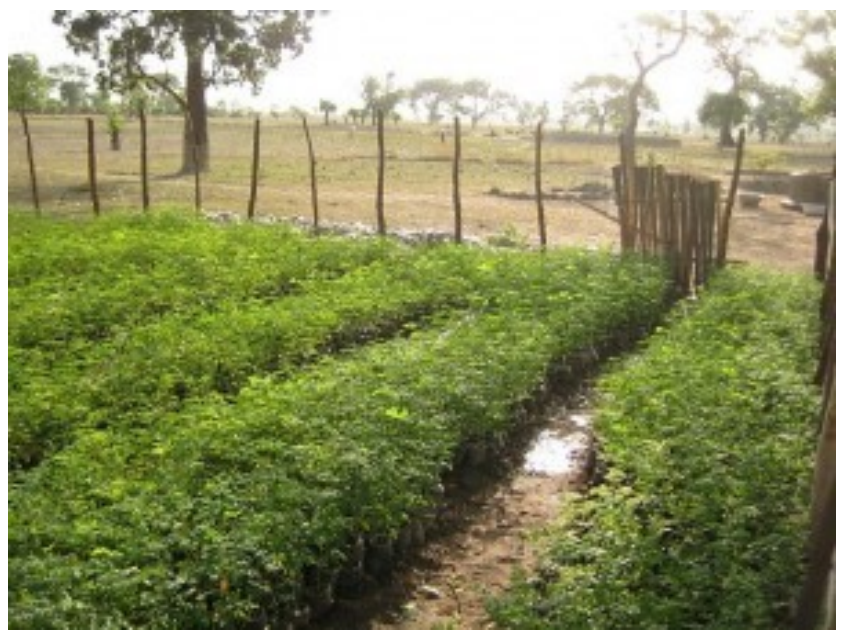

Figure 8. Planting of moringa oleifera bio in monoculture [5]

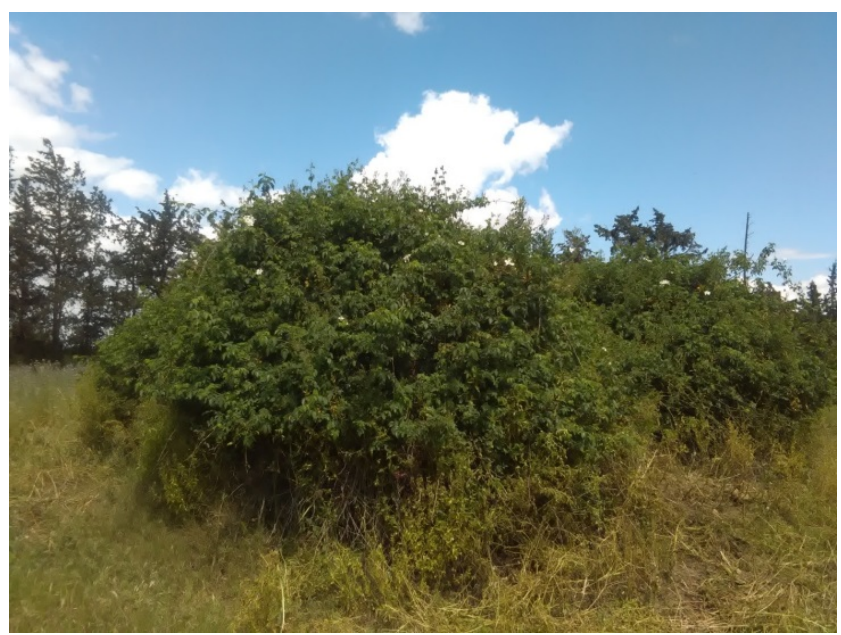

Figure 9. The aromatic and medicinal shrub rose has been cultivated at the ESA Mograne experimental station (April 2017)

A research project on shrub rose led to the ESA Mograne used different varieties from all over Tunisia. Figure 9 shows a line of planting of rose hips in April 2017, which can be used in strip cropping systems on moderate hillslopes.

\section{Conclusions}

To control water erosion, water scarcity and to improve population income in Tunisian semi-arid area on moderate hillslopes (less than 10\%), study of the effects of two crop system and best management practices on soil and water conservation have been conducted. Tunisian semi-arid area is characterized by rainfall irregularity and aggressivity, poor soil organic matter, overgrazing and poor population.

Thus to protect natural and human environments, two main crops in Tunisia were used: chickpea and olive tree. The two cropping system and best management practices used are:

- chickpea after long-term fallow soil as grazing area;

- $\quad$ row olive mill waste water as organic fertilizer and organic herbicide.

Results showed that:

1. Use of spring chickpea induced an increase of soil organic matter content between the initial state and the final state of the soil, related to field position within slope direction;

2. The length of the plant and the internodes are strongly correlated with the $\mathrm{C} / \mathrm{N}$ soil ratio after harvesting, while the percentage of dry matter and the weight of 1000 grains are highly correlated with the final soil moisture;

3. Use of row olive mill waste water as organic fertilizer and organic herbicide (80 to $100 \mathrm{~m}^{3} / \mathrm{ha}$ ) in olive orchard, showed:

- Improvement of soil structure and macro porosity ;

- Increase in the normal shear stress of the soil and therefore a better mechanical resistance of the soil to water erosion;

- Increase of the water holding capacities of treated plots after treatment, which become close to the water holding capacity of the witness plot after 4 months of application.

- Variation of the floristic composition (Weeds) of the soil, depending on the treatment. So that 6 weed species can resist to high value of applied olive mill waste water $\left(200 \mathrm{~m}^{3} / \mathrm{ha}\right)$.

Finally to cope with climate change and food security, new crop systems for water and soil conservation and economic gain are needed. Use and adaptation of some new crop associations used all over the world (e.g. Cowpea-sorghum in Burkina Faso, cereal/safflower, moringa oleifera, stevia and aromatic and medicinal plants 
like shrub rose in Tunisia). Organic fertilization, law carbon emission, nitrogen fixation, high food protein value and human health protection are criteria used for crop selection.

\section{REFERENCES}

[1] Ben Khlif A., 2009. Etude de l'Effet de l'Epandage de Trois Doses de Margine sur Certains Paramètres et sur l'Infiltration d'un Sol Argilo-sableux dans le Région de Zaghouan. Mémoire de Mastère en Gestion des Ressources Naturelles de l'ESA de Mograne.
[2] Laajili Ghezal, L., Aloui, T., Beji, M.A. \& Zekri, S., 1998. Optimization of Soil and Water Conservation Techniques in a Watershed of the Tunisian Semi-Arid Region. Advances in GeoEcology 31, 341-354, CATENA VERLAG.

[3] Masson, J.M., 1971. L'Erosion des sols par l'eau en climat Méditerranéen. Méthodes expérimentales pour l'étude des quantités érodées à l'échelle du champ. Thèse de Docteur-Ingénieur. Ecole Nationale Supérieure Agronomique de Nancy, Université des Sciences et Techniques du Languedoc, C.N.R.S., République Française, 213 pp.

[4] Zougmoré R., Kambou F. \& Ouattara K., 2000. Utilisation de l'association sorgho-niebe pour réduire le ruissellement et l'érosion. Fiche technique ${ }^{\circ} 3$.

[5] www.moringa.biologique.bio/culture-plantation 